\title{
MENINGKATKAN MOTIVASI LAYANAN BIMBINGAN KLASIKAL DENGAN METODE SOSIODRAMA PADA SISWA SMP
}

\author{
SITI NURHARNANIK \\ SMP Negeri 10 Malang \\ e-mail: sitinurharnanik10@gmail.com
}

\begin{abstract}
ABSTRAK
Penelitian ini bertujuan untuk meningkatkan motivasi mengikuti layanan bimbingan klasikal dengan metode sosiodrama pada siswa SMP. Subyek penelitian adalah 30 siswa kelas VIII-I SMPN 10 Malang. Penyebab rendahnya motivasi siswa dalam mengikuti bimbingan klasikal salah satunya adalah guru masih menggunakan metode konvesional yaitu metode ceramah murni. Solusi untuk mengatasi permasalahan tersebut peneliti menggunakan metode sosiodrama. Penelitian ini dilaksanakan dengan rancangan penelitian tindakan kelas yang prosedur pelaksanaannya mengikuti prinsip dasar penelitian tindakan yang umum. Prosedur tersebut merupakan suatu proses siklus atau daur ulang, yang dimulai dari tahap perencanaan, tahap pelaksanaan tindakan, tahap observasi/evaluasi, dan tahap refleksi. Pelaksanaan penelitian ini dilakukan sebanyak dua siklus. Hasil penelitian menunjukkan adanya peningkatan dari siklus pertama ke siklus kedua. Berdasarkan data hasil penelitian pada siklus pertama dan siklus kedua, semua indikator mengalami peningkatan keberhasilan sesuai dengan yang diharapkan. Hasil observasi siklus I, rata-rata mencapai 62\% sedangkan siklus II mencapai $75 \%$, ini artinya dari siklus I ke Siklus II meningkat $13 \%$.
\end{abstract}

Kata Kunci: Sosiodrama, klasikal

\section{ABSTRACT}

This study aims to increase motivation to follow classical guidance services with the sociodrama method for junior high school students. The research subjects were 30 students of class VIII-I of SMPN 10 Malang. One of the causes of the low motivation of students in following classical guidance is the teacher still uses the conventional method, namely the pure lecture method. The solution to overcome these problems, researchers use the sociodrama method. This research was conducted with a classroom action research design whose implementation procedure follows the basic principles of general action research. The procedure is a cyclical or recycling process, starting from the planning stage, the action implementation stage, the observation/evaluation stage, and the reflection stage. The implementation of this research was carried out in two cycles. The results showed an increase from the first cycle to the second cycle. Based on the research data in the first and second cycles, all indicators have increased success as expected. The results of the first cycle observations, the average reached $62 \%$ while the second cycle reached $75 \%$, this means from the first cycle to the second cycle an increase of $13 \%$.

Keywords: Sociodrama, classical

\section{PENDAHULUAN}

Bimbingan dan konseling di sekolah diselenggarakan untuk memfasilitasi perkembangan peserta didik agar mampu mengaktualisasikan potensi dirinya dalam rangka mencapai perkembangan secara optimal. Fasilitasi dimaksudkan sebagai upaya memperlancar proses, karena secara kodrati setiap manusia berpotensi untuk berkembang.

Peserta didik SMP adalah individu yang sedang berkembang. Untuk mencapai perkembangan optimal, potensi-potensi peserta didik perlu difasilitasi melalui berbagai komponen pendidikan, yang salah satu di antaranya adalah layanan Bimbingan dan Konseling.

Layanan Bimbingan dan Konseling saat ini merupakan upaya pengembangan potensipotensi positif individu. Semua peserta didik berhak mendapatkan layanan bimbingan dan konseling agar potensi-potensi positif yang mereka miliki dapat berkembang optimal. Untuk 
mengembangkan potensi-potensi positif diperlukan strategi yang tepat agar layanan Bimbingan dan konseling lebih efesien.

Layanan bimbingan klasikal merupakan kegiatan layanan yang diberikan kepada sejumlah peserta didik dalam satu rombongan belajar dan dilaksanakan di kelas dalam bentuk tatap muka antara guru BK dengan peserta didik.

Tujuan layanan Bimbingan Klasikal membantu peserta didik dapat mencapai kemandirian dalam kehidupannya, perkembangan yang utuh dan optimal dalam bidang pribadi, sosial, belajar dan karir serta mencapai keselarasan antara pikiran, perasaan dan perilaku. Interaksi sosial yang intensif dan dinamis selama pelaksanaan bimbingan klasikal diharapkan dapat memenuhi kebutuhan-kebutuhan individu secara mantap.

Menurut pengamatan Peneliti, proses belajar mengajar di SMP Negeri 10 Malang berjalan cukup bagus, karena didukung guru yang berdedikasi terhadap tugasnya, didukung sarana prasarana belajar yang sangat memadai seperti ruang kelas yang bersih, media dan sumber pembelajaran yang lengkap, juga adanya tambahan kegiatan keagamaan yang cukup seperti sholat berjamaah, membaca Alqur'an setiap pagi selama 20 menit, solat Jum'at yang sudah dijadwalkan. Dengan kondisi ini mestinya siswa SMP Negeri 10 Malang bisa menjalani proses belajar mengajar dengan baik, yang ditunjukan dengan adanya motivasi belajar tinggi.

Namun kondisi nyata di lapangan tidaklah menunjukan kondisi ideal yang diharapkan, dari hasil pengamatan ditemukan permasalahan yang ada di kelas VIII I jika mengikuti bimbingan klasikal menunjukan motivasi yang rendah, hal ini ditunjukkan dari 30 siswa hanya ada 9 anak yang aktif mengikuti layanan bimbinan klasikal. Ini berarti hanya ada $30 \%$ yang memiliki motivasi tinggi sedangkan yang $70 \%$ masih memiliki motivasi rendah. Penyebab rendahnya motivasi siswa dalam mengikuti layanan bimbingan klasikal salah satunya adalah Guru BK masih cenderung menggunakan metode konvensional yaitu metode ceramah murni. Metode ceramah merupakan suatu cara penyampaian bahan pelajaran secara lisan dari guru. Ceramah yang baik adalah ceramah bervarisasi artinya ceramah yang dilengkapi dengan pengguanaan alat dan media serta adanya tambahan dialog interaktif atau diskusi sehingga proses pembelajaran tidak menjenuhkan.

Salah satu solusi yang peneliti pandang bermanfaat untuk mengatasi masalah rendahnya motivasi siswa dalam mengikuti layanan bimbingan klasikal adalah merubah metode yakni dari metode konvensional menjadi metode yang lebih memberi kebebasan siswa untuk beraktifitas yaitu metode sosiodrama. Menurut Djamarah dan Zain (2010) metode sosiodrama melatih siswa untuk berinisiatif, berkreatif dan menanamkan kebiasaan kepada siswa untuk menerima dan membagi tanggung jawab dengan sesamanya. Tohirin (2007) menyatakan sosiodrama dapat digunakan sebagai salah satu cara bimbingan kelompok. Sosiodrama merupakan suatu cara membantu memecahkan masalah siswa melalui drama. Sesuai namanya, masalah-masalah yang didramakan adalah masalah sosial.

Dari fenomena-fenomena di atas maka penulis akan mengadakan penelitian tindakan guru BK dengan judul: Usaha Meningkatkan Motivasi Layanan Bimbingan Klasikal dengan Menggunakan Metode Sosiodrama pada Siswa Kelas VIII I semester 1 SMP Negeri 10 Malang Tahun Pelajaran 2020//2021

\section{METODE PENELITIAN}

Metode yang digunakan dalam penelitian ini adalah layanan bimbingan klasikal dengan metode sosiodrama. Metode sosiodrama merupakan suatu layanan yang diberikan oleh konselor atau guru pembimbing kepada anggota dalam situasi kelompok untuk membahas sebuah topik permasalahan yang akan dikemas dalam bentuk sebuah drama. Metode sosiodrama ini bertujuan supaya siswa atau anggota mudah memahami topik yang dibahas dalam kegiatan bimbingan klasikal, selain itu juga melatih kreatifitas siswa dalam bermain peran.

Subjek penelitian dalam proses pelaksanaan Penelitian Tindakan Kelas ini yaitu peserta didik kelas VIII-I SMP Negeri 10 Malang. Lokasi penelitian dilaksakana di kelas VIII-I SMP 
Negeri 10 Malang. Adapun waktu penelitian dilakukan pada semester II ( genap) tahun pelajaran 2020/2021.

Prosedur Penelitian Tindakan Guru BK dirancang berdasarkan pada keinginan penulis untuk meningkatkan motivasi siswa dalam mengikuti layanan bimbingan klasikal. Dalam meningkatkan motivasi siswa mengikuti layanan bimbingan klasikal ini dirancang dalam bentuk dua siklus, setiap siklus terdiri dari empat tahapan yaitu perencanaan, pelaksanaan, observasi dan refleksi. Desain penelitian Tindakan Guru BK didesain sebagai berikut:

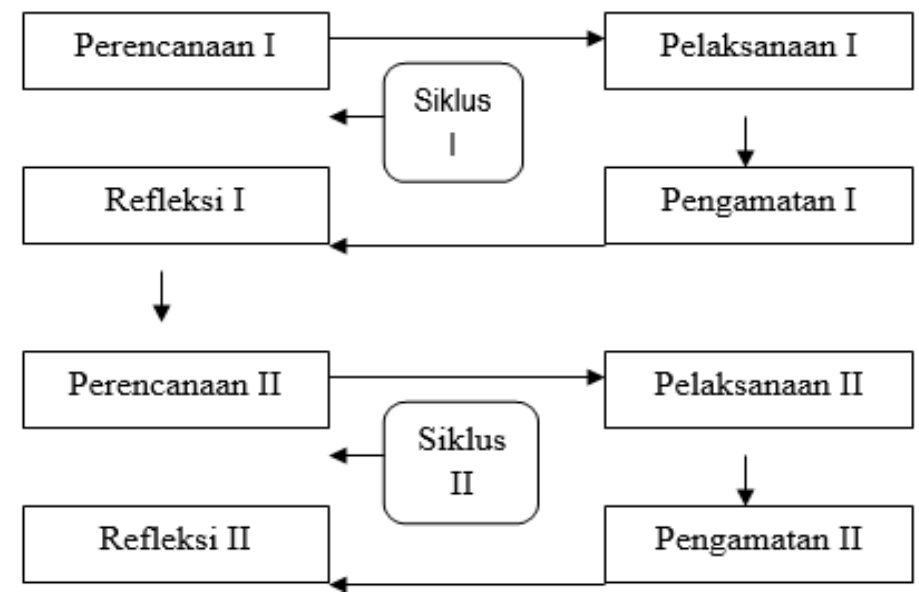

Gambar 1. Desain Penelitian

Pengumpulan data pada penelitian ini dengan observasi serta dokumentasi. Pada instrumen observasi, obyek yang diamati adalah keaktifan siswa mengikuti sosiodrama., pemahaman siswa terhadap perasaan orang lain, keberanian siswa dalam bertanya, keberanian siswa dalam mengemukakan pendapat, dan keberanian siswa dalam menjawab pertanyaan.

\section{HASIL DAN PEMBAHASAN}

\section{Hasil}

Siklus I :

Selama proses layanan Bimbingan Klasikal dengan metode sosiodrama berlangsung penulis bekerja sama dengan teman sejawat (kolaborator) untuk membantu mengadakan observasi. Rekapitulasi hasil observasi Bimbingan Klasikal dengan metode sosiodrama siklus I tertera pada tabel 1. sebagai berikut:

Tabel 1. Hasil Observasi Siklus I

\begin{tabular}{|l|c|c|}
\hline Sasaran Observasi & Jumlah & prosentase \\
\hline Keaktifan siswa mengikuti sosiodrama & 21 & $70 \%$ \\
\hline Pemahaman siswa terhadap perasaan orang lain & 18 & $60 \%$ \\
\hline Keberanian siswa dalam bertanya, & 17 & $57 \%$ \\
\hline $\begin{array}{l}\text { Keberanian siswa dalam mengemukakan } \\
\text { pendapat }\end{array}$ & 17 & $57 \%$ \\
\hline Keberanian siswa dalam menjawab pertanyaan & 20 & $67 \%$ \\
\hline \multicolumn{1}{|c|}{ Rata-rata /Tinggi Motivasi secara klasikal } & & $62 \%$ \\
\hline
\end{tabular}

Dari hasil observasi tersebut di atas dapat dijelaskan bahwa dari 30 siswa kelas VIII-I yang mengikuti layanan Bimbingan Klasikal dengan metode sosiodrama dapat dijelaskan sebagai berikut: Keaktifan siswa mengikuti sosiodrama ada 21 anak atau 70\%, Pemahaman siswa terhadap perasaan orang lain ada 18 anak atau 60\%, Keberanian siswa dalam bertanya ada 17 anak atau 57\%, Keberanian siswa dalam mengemukakan pendapat ada 17 anak atau $57 \%$, dan Keberanian siswa dalam menjawab pertanyaan ada 20 anak atau 67\%, jika diratarata, siswa yang motivasinya tinggi ada $62 \%$ 
Siklus II:

Rekapitulasi hasil pengamatan siklus II tertera pada tabel 2. sebagai berikut:

Tabel 2. Hasil Observasi Siklus II

\begin{tabular}{|l|r|c|}
\hline \multicolumn{1}{|c|}{ Sasaran Observasi } & Jumlah & prosentase \\
\hline Keaktifan siswa mengikuti sosiodrama & 25 & $83 \%$ \\
\hline Pemahaman siswa terhadap perasaan orang lain & 23 & $76 \%$ \\
\hline Keberanian siswa dalam bertanya, & 23 & $76 \%$ \\
\hline Keberanian siswa dalam mengemukakan pendapat & 22 & $73 \%$ \\
\hline Keberanian siswa dalam menjawab pertanyaan & 23 & $77 \%$ \\
\hline Rata-rata /Tinggi Motivasi secara klasikal & & $77 \%$ \\
\hline
\end{tabular}

Dari hasil observasi tersebut di atas dapat dijelaskan bahwa dari 30 siswa kelas VIII I yang mengikuti layanan Bimbingan Klasikal dapat dijelaskan sebagai berikut: Keaktifan siswa mengikuti sosiodrama ada 24 siswa atau $83 \%$, pemahaman siswa terhadap perasaan orang lain ada 23 siswa atau $76 \%$, keberanian siswa dalam bertanya ada 23 atau $76 \%$, keberanian siswa dalam mengemukakan pendapat ada 22 siswa atau 73\%, dan keberanian siswa dalam menjawab pertanyaan ada 23 siswa atau $77 \%$. Jika dirata-rata siswa yang aktif atau yang memiliki motivasi tinggi sebesar $77 \%$

Hasil penelitian siklus I dan II akan dirangkum dalam tabel 3. sbb:

Tabel 3. Hasil Observasi Siswa Siklus I dan II

\begin{tabular}{|l|c|c|c|}
\hline \multirow{2}{*}{\multicolumn{1}{|c|}{ Sasaran Observasi }} & \multicolumn{3}{c|}{ Siklus } \\
\cline { 2 - 4 } & I & II & Naik \\
\hline Keaktifan siswa mengikuti sosiodrama & $70 \%$ & $83 \%$ & $13 \%$ \\
\hline Pemahaman siswa terhadap perasaan orang lain & $60 \%$ & $76 \%$ & $16 \%$ \\
\hline Keberanian siswa dalam bertanya, & $57 \%$ & $76 \%$ & $19 \%$ \\
\hline $\begin{array}{l}\text { Keberanian siswa dalam mengemukakan } \\
\text { pendapat }\end{array}$ & $57 \%$ & $73 \%$ & $16 \%$ \\
\hline Keberanian siswa dalam menjawab pertanyaan & $67 \%$ & $77 \%$ & $10 \%$ \\
\hline \multicolumn{1}{|c|}{ Rata-rata /Tinggi Motivasi secara klasikal } & $62 \%$ & $77 \%$ & $15 \%$ \\
\hline
\end{tabular}

Peningkatan motivasi siswa dalam Bimbingan Klasikal siklus I sampai dengan siklus II dapat digambarkan sebagai mana tertera dalam diagram 1 sebagai berikut:

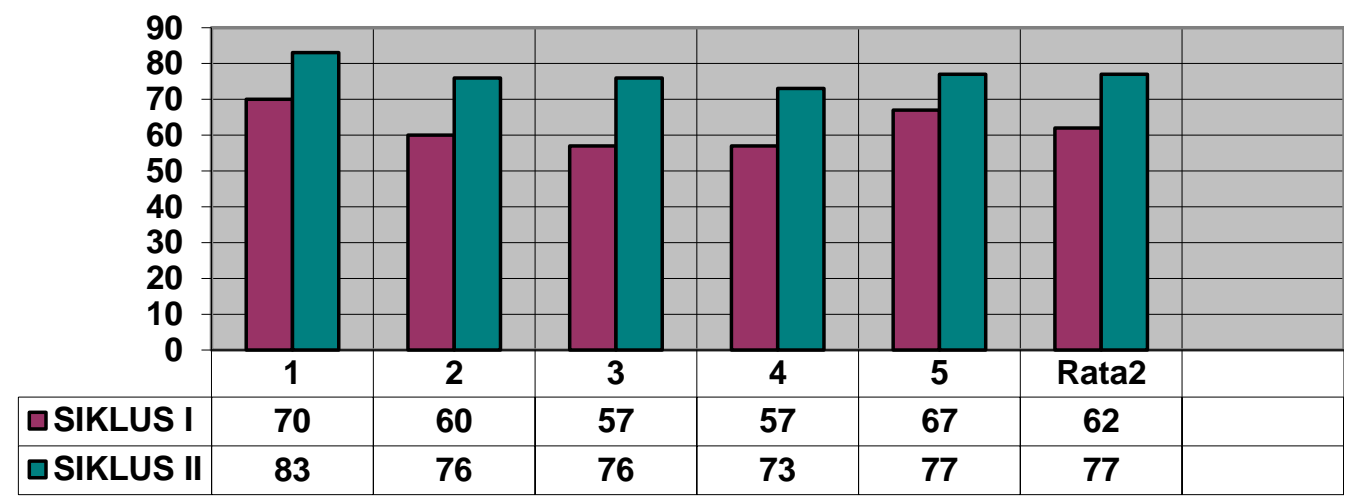

Gambar 2. Diagram Perkembangan Siswa dalam Bimbingan Klasikal Siklus I dan II

\section{Pembahasan}

Berdasarkan hasil analisis data siklus I sampai siklus II yang telah diuraikan sebelumnya diperoleh hasil penilaian bahwa penerapan bimbingan klasikal dengan menggunakan metode 
sosiodrama dapat memberikan pengaruh yang signifikan terhadap peningkatan motivasi siswa dalam mengikuti layanan bimbingan klasikal di kelas VIII-I SMP Negeri 10 Malang.

Keaktifan siswa mengikuti sosiodrama semakin meningkat, hal tersebut karena adanya factor : a) metode sosiodrama mampu membuat proses layanan bimbingan klasikal lebih hidup dan menarik bagi siswa, b) metode sosiodrama sangat cocok digunakan untuk kegiatan bimbingan klasikal, c) siswa sangat luar biasa penampilanya dalam sosiodrama, hal ini disebabkan karena mereka merasa tampilannya akan dinilai.

Pemahaman siswa terhadap perasaan orang lain semakin meningkat, hal tersebut karena adanya factor: a) pemahaman Karakter, salah satu kelebihan sosiodrama adalah membuat pemeran mampu memahami perasaan orang lain, b) siswa mulai mampu memerankan peran sesuai yang diharapkan, hal ini disebabkan oleh karena mereka bersama-sama membuat teks dialog, bahkan mereka membagi peran berusaha mencari orang seperti karakter yang akan diperankannya, c) siswa sudah mampu memerankan perannya, mereka banyak yang melakukan imrofisasi sehingga nampak seperti pertunjukkan sesungguhnya.

Keberanian siswa dalam bertanya dari siklus I sampai siklus II semakin meningkat. Hal tersebut karena adanya factor : a) berkat dorongan dari guru siswa mulai ada keberanian bertanya, b) dorongan yang besar yang berasal dari diri anak, karena ingin mengetahui apa yang belum diketahui akan menggerakan anak untuk berbuat dalam rangka mengetahui apa yang belum mereka ketahui, c) anak yang mempunyai dorongan yang tinggi cenderung menyeleksi perbuatannya yaitu mana yang harus diperbuat dan mana yang harus diabaikan.

Keberanian siswa dalam mengemukakan pendapat dari siklus I sampai siklus II semakin meningkat. Hal tersebut karena adanya factor: a) apa yang dilakukan anak entah itu pendapatnya sudah benar atau belum benar apa bila dipuji dengan waktu dan cara yang tepat anak akan merasa tersanjung, sehingga anak lebih percaya diri walau siswa masih ragu dengan kebenaran dari pendapatnya, b) persaingan kemampuan antar individu atau kelompok dapat mendorong siswa untuk melakukan sesuatu perbuatan, c) anak sudah mulai percaya diri, anak mulai ada rasa persaingan yang sehat, hal ini tidak luput dari peran guru yang selalu memuji pendapat siswanya.

Keberanian siswa dalam menjawab pertanyaan dari siklus I sampai siklus II semakin meningkat. Hal tersebut karena adanya factor : a) minat adalah suatu rasa senang yang dimiliki anak untuk melakukan aktivitas yang telah diketahui kebaikannya oleh karena itu, apa yang ditanyakan guru siswa langsung angkat tangan dan menjawab dengan penuh keyakinan, b) hasrat menjawab pertanyaan semakin tinggi karena siswa jika menjawab pertanyan yang belum tentu benar, selalu mendapat tepuk tangan dari gurunya juga dari temannya, c) Anak yang sejak awal sudah memiliki rasa percaya diri, maka untuk mempertahankan rasa harga dirinya mereka selalu angkat tangan untuk ikut menjawab pertanyaan yang diajukan guru.

Penelitian yang relevan: 1) Penelitian Imam, M (2019) yang berjudul "Peningkatan Interaksi Sosial Teman Sebaya Siswa SMP Melalui Bimbingan Klasikal Dengan Metode Sosiodrama" menyatakan bahwa bimbingan klasikal dengan metode sosiodrama dapat meningkatkan kemampuan berinteraksi sosial siswa; 2)Penelitian Sutoyo, dkk (2014) yang berjudul "Pengembangan Model Bimbingan Kelompok dengan Teknik Sosiodrama untuk Meningkatkan Penyesuaian Diri Siswa" menyatakan bahwa model layanan klasikal dengan teknik sosiodrama terbukti mampu untuk meningkatkan penyesuaian diri siswa sebesar 11,7\%; 3) Penelitian Alisyahbana, I. B. Yang berjudul "Meningkatkan Perilaku Sopan Santun Melalui Layanan Bimbingan Kelompok Dengan Teknik Sosiodrama Di Sekolah" menyatakan bahwa penelitian tindakan dalam bimbingan dan konseling melalui penggunaan teknik sosiodrama dalam layanan bimbingan kelompok dapat meningkatkan perilaku sopan peserta didik di sekolah dan perilaku peserta didik yang mengalami peningkatan dapat diketahui bahwa teknik sosiodrama efektif digunakan dalam layanan Bimbingan kelompok.

Dengan demikian, berdasarkan kesimpulan para peneliti yang relevan dan hasil data yang diperoleh, maka dapat dikatakan bahwa penggunaan metode sosiodrama dapat 
meningkatkan motivasi siswa VIII-I SMP Negeri 10 Malang Tahun Pelajaran 2020/2021 dalam mengikuti layanan bimbingan klasikal.

\section{KESIMPULAN}

Berdasarkan hasil penelitian dan pembahasan yang dikemukakan dalam bab hasil dan pembahasan, maka dapat disimpulkan bahwa: "Metode sosiodrama dapat meningkatkan motivasi layanan Bimbingan Klasikal pada Siswa Kelas VIII I semester 1 SMP Negeri 10 tahun pelajaran 2020/2021". Hal ini Sesuai dengan hasil observasi sebagai berikut: Hasil observasi siklus I, rata-rata mencapai $62 \%$ sedangkan siklus II mencapai $77 \%$, ini artinya dari siklus I ke siklus II meningkat $15 \%$. Permasalahan yang terjadi di kelas VIII I ketika mengikuti bimbingan klasikal dengan metode konvensional, motivasi siswa rendah yaitu mencapai $70 \%$, ini berarti hanya sekitar $30 \%$ siswa yang mempunyai motivasi tinggi. Namun setelah menggunakan metode sosiodrama motivasi siswa dalam mengikuti layanan bimbingan klasikal dari siklus I ke siklus II meningkat menjadi $77 \%$

\section{DAFTAR PUSTAKA}

Depdiknas, 2005. Pedoman Pelaksanaan Bimbingan dan Konseling, Jakarta Depdiknas

Djamarah, S. \& Zain, A. 2010. Strategi Belajar Mengajar. Jakarta: Asdi Mahasatya

Djamarah, S. 2010. Guru dan Anak Didik dalam Interaksi Edukatif. Jakarta: Asdi Mahasatya

Djamarah, S. B. 2002. Psikologi Belajar. Jakarta: C.V.Trineka Cipta.

Gulo, W. 2002. Strategi Belajar Mengajar. Jakarta: Grasindo

Imam, M. 2019. Peningkatan Interaksi Sosial Teman Sebaya Siswa SMP Melalui Bimbingan Klasikal Dengan Metode Sosiodrama

Kemendikbud. 2016. Pedoman Bimbingan Dan Konseling Pada Pendidikan Dasar Dan Pendidikan Menengah. Jakarta: Depdikbud

Mulyasa. 2003. Bimbingan Klasikal. Surabaya: Depdikbud

Rahman, S. 2006. Konseling dan Psikoterapi. Jakarta: BPK Gunung Mulia

Roestiyah. 2012. Strategi Belajar Mengajar. Jakarta: Asdi Mahasatya

Romlah, T. 2013. Teori dan Praktek Bimbingan Kelompok. Malang: Universitas Negeri Malang Sardiman. 2006. Bimbingan di Sekolah, Jakarta: Bina Aksara

Sayekti. 1997. Berbagai Pendekatan dalam Konseling. Yogyakarta: Menara Mass Offset

Sutoyo, A. dan dkk. 2014. Pengembangan Model Bimbingan Kelompok dengan Teknik Sosiodrama untuk Meningkatkan Penyesuaian Diri Siswa. Bimbingan Konseling

Tohirin. 2007. Bimbingan dan Konseling di Sekolah dan Madrasah. Jakarta: Rajawali Press

Willis S. S. 2007. Konseling Individual. Teori dan Praktek. Bandung: Alfabeta 